\title{
Adapted Primary Literature in Authentic Science: Students' Perception
}

\author{
Toni Hidayat ${ }^{*}$, Nuryani Rustaman ${ }^{1}$, Parsaoran Siahaan ${ }^{1}$ \\ ${ }^{1}$ Sekolah Pascasarjana, Universitas Pendidikan Indonesia, Bandung, Indonesia \\ *Corresponding Author. tonihidayatbinhasan@gmail.com
}

\begin{abstract}
Science textbooks only present scientific facts that cause the textbooks to seem not to promote scientific reasoning. Science learning also becomes not in line with the nature of Science. Then, Science learning requires applying authentic Science as an approach. Adapted Primary Literature (APL) is assumed to be able to achieve this objective. Therefore, this study aims to examine how APL is a source of Science learning in actualizing authentic Science. This research using a quasi-experimental method, 81 students from two 7th grade groups were involved as participants. One group analyzed APL using a jigsaw, another using a Numbered Heads Together (NHT). A perception questionnaire of APL was given. Quantitative analysis was only performed on data from 44 students due to other students' participation that is lacked by a pandemic. The result showed both classes possess a high perception of APL. A mean difference test also showed that there were no differences in perception between the two classes. These indicated that analyzing APL was perceived as an authentic Science. Science teachers can utilize APL as an alternative way to actualize authentic Science with a relatively more straightforward model, strategy, and method than commonly applied.
\end{abstract}

Keywords Adapted primary literature, Authentic science, Students’ perception

\section{INTRODUCTION}

Science textbooks only present various scientific facts without inviting students to think scientifically (Ariely, Livnat \& Yarden, 2019a; Rusilowati, 2014; Vesterinen, Aksela \& Lavonen, 2013; Wahyu \& Markos, 2016). When learning Science, students do not read texts that reflect authentic scientific reasoning (Ariely, Livnat \& Yarden, 2019a, 2019b). Reading Science texts does not mean doing Science if the reading activities only obtain facts (Cervetti \& Pearson, 2012). This causes the difference between Science in school and real Science. Meanwhile, Science in school must be in line with the nature of Science (McCoach, Gable \& Madura, 2013; Tala \& Vesterinen, 2015; Upahi, Ramnarain, \& Ishola, 2018).

A means to actualize Science learning that reflects natural Science is an authentic Science. Authentic Science is a Science learning approach that provides opportunities for students to think (Crawford, 2013; Labouta et al., 2018), work (Anker-Hansen \& Andrée, 2019; Chapman \& Feldman, 2017; Crawford, 2013; Koomen, Rodriguez, Hoffman, Petersen, \& Oberhauser, 2018; Machluf, Gelbart, Ben-Dor \& Yarden, 2017) and feel like scientists. Authentic Science is also an approach to teach Science based on the inquiry process (Anker-Hansen \& Andrée, 2019; Broder et al., 2019; Hellgren \& Lindberg, 2017;
Koomen, Rodriguez, Hoffman, Petersen, \& Oberhauser, 2018; Labouta et al., 2018; Olitsky, Becker, Jayo, Vinogradov, \& Montcalmo, 2020; Tsybulsky, 2019). Therefore, Science teaching and learning will be studentcentered (Anker-Hansen \& Andrée, 2019; Buxton, 2006; Labouta et al., 2018; Rivera Maulucci, Brown, Grey, \& Sullivan, 2014; Ward et al., 2016) and also require students' independence (Koomen, Rodriguez, Hoffman, Petersen, \& Oberhauser, 2018; Labouta et al., 2018; Machluf, Gelbart, Ben-Dor, \& Yarden, 2017; Olitsky, Becker, Jayo, Vinogradov \& Montcalmo, 2020; Rivera Maulucci, Brown, Grey, \& Sullivan, 2014; Ward et al., 2016).

Authentic Science can be actualized with researchbased learning activities (Chapman, 2013; Chapman \& Feldman, 2017; Rivera Maulucci, Brown, Grey, \& Sullivan, 2014), in the laboratory (Chapman \& Feldman, 2017; Labouta et al., 2018; Munn, Knuth, Van Horne, Shouse \& Levias, 2017; Olitsky, Becker, Jayo, Vinogradov, \& Montcalmo, 2020; Rivera Maulucci, Brown, Grey, \& Sullivan, 2014) or out of school (Hellgren \& Lindberg, 2017; Koomen, Rodriguez, Hoffman, Petersen, \&

\footnotetext{
Received : 17 March 2021

Revised : 22 April 2021

Published : 1 August 2021
} 
Oberhauser, 2018; Ward et al., 2016). Authentic Science can also be actualized by inviting scientists into Science classes (Tsybulsky, 2019), inviting students to have tours in universities and the laboratories (Chapman \& Feldman, 2017; Olitsky, Becker, Jayo, Vinogradov, \& Montcalmo, 2020; Tsybulsky, 2019), conducting Science exhibitions (Koomen, Rodriguez, Hoffman, Petersen, \& Oberhauser, 2018; Rivera Maulucci et al., 2014), and visiting museums (Achiam, Simony \& Lindow, 2016). Nevertheless, the learning models, strategies, and methods mentioned above seem to require plenty of teachers' and students' effort to actualize authentic Science. Science teachers need a more straightforward model, strategies, or methods.

Authentic Science imitates what scientists do. The scientists employ about $23 \%$ of their work time to read (Phillips \& Norris, 2009). Of course, the intended reading is Primary Scientific Literature (PSL) to support their work as scientists. However, scientific language in PSL is complex for students to understand (Ariely, Livnat \& Yarden, 2019a). Then, several obstacles allegedly arise when Science teachers assign students to read PSL. The teachers possibly need to use an adapted version of PSL, namely Adapted Primary Literature (APL). The genre, structure, writing content, and science presentation in APL are maintained equal to PSL (Ariely, Livnat \& Yarden, 2019a; Yarden, 2009; Yarden, Norris, \& Phillips, 2015a). The differences are in the objectives, authors, and readers target (Ariely, Livnat \& Yarden, 2019a; Yarden, 2009; Yarden, Norris, \& Phillips, 2015a). Even though APL is an adaptation, utilizing APL in Science learning can actualize authentic Science.

Moreover, Science teachers in middle school possess a high positive perception toward APL (Hidayat, Rustaman \& Shidiq, 2020). Therefore, this study has the first research question: can APL actualize authentic Science? If the result shows what is assumed, authentic Science can be actualized by applying a learning model, strategy, and method that is relatively more straightforward.

On the other hand, middle school students experience a transition in reading skills, from learning-to-read to reading-to-learn. Several students encounter barriers in this stage (Fang, 2006). In line with that, Indonesian middle school students' reading skills and science achievement are still below the average of the OECD country (OECD, 2019). Science learning that requires them to read allegedly reduces their involvement in the learning activity. Furthermore, students are assigned to read scientific texts. Even though students read the adapted version of the PSL, researchers suspected that these obstacles may still arise. Cooperative learning models should be applied to allow students to assist each other (Slavin, 2012). This is expected to boost their involvement in the learning activity because cooperative learning may be better than traditional techniques when the learning outcome is at a high cognitive level (Slavin, 1980), such as analyzing APL.
Jigsaw and Numbered Heads Together (NHT) were determined as the learning models in this study. These two learning models are believed to be widely known among teachers. Consequently, science teachers can be relatively easy to implement the result of this study into their teaching and learning activity. Moreover, the jigsaw can be primarily used in learning that reading text is an essential part of the learning activity (Li \& Lam, 2013). The jigsaw can also improve students reading comprehension (Nurbianta \& Dahlia, 2018), enhance student motivation to learn Science (Tarhan, Ayyldız, Ogunc \& Sesen, 2013), enhance student involvement in a learning activity (Goolsarran, Hamo, \& Lu, 2020), and improve student learning outcomes (Doymus, 2008; (Goolsarran, Hamo \& Lu, 2020); Tarhan, Ayylldı, Ogunc \& Sesen, 2013; Yoruk, 2016). The NHT can improve students' reading skills, enhance student participation in learning, particularly in the question and answer session (Purnomo, 2012), and improve student learning outcomes (Leasa \& Corebima, 2017; Mulyana, Hanifah, \& Jayadinata, 2016). The researchers consider that learning science using APL will be more effective if performed in these two types of cooperative learning. A question arises between the two, which is more effective. Therefore, this study has the second research question: which model is considered more effective in actualizing authentic Science, jigsaw, or NHT? Finding the answer to this second research question can aid the Science teachers to determine which learning models they can apply in their learning to be more effective in actualizing authentic Science.

In addition, the context of this study has to determine carefully. Environmental pollution is considered an appropriate topic in this study. They consider that environmental pollution has occurred on soil, water, and the air around students' live areas. The pollution seems to be getting worse. Rice fields are polluted by heavy metals from untreated textile factory waste (Komarawidjaja, 2017). Water in the dug well was contaminated by Coliform bacteria. The bacteria are thought to have come from animal cages, septic tanks, plantations, and fish ponds (Prilia \& Kamil, 2011). The level of carbon monoxide in the blood of people who work in places with air pollution sources correlates with the levels of carbon monoxide in the air of that place (Fitriana \& Oginawati, 2012). By raising the topic of problems that occur in the students' lives, it is expected to increase the possibility of actualizing authentic Science.

\section{METHOD}

\subsection{Research Method}

This study used a quantitative approach and a quasiexperimental method (Fraenkel, Wallen, \& Hyun, 2012). Students learn about environmental pollution by reading, analyzing, and discussing APL. After that, students were given a posttest to ask their perceptions about the learning conducted in actualizing authentic Science. Since APL is 
Table 1 Questionnaire rubric of students' perceptions of APL in actualizing authentic science

\begin{tabular}{lll}
\hline Rubric of Statements & Example Statement & Number of Items \\
\hline Students think like a scientist when reading APL & $\begin{array}{l}\text { When reading APL, several questions arose } \\
\text { in my mind about the topic in the APL }\end{array}$ & 5 \\
Students work like a scientist when reading APL & $\begin{array}{l}\text { I made a writing based on data/information } \\
\text { in APL that I read } \\
\text { Students feel like a scientist when reading APL }\end{array}$ & $\begin{array}{l}\text { After reading APL, I was interested in } \\
\text { conducting research }\end{array}$ \\
\hline
\end{tabular}

Table 2 Participants data

\begin{tabular}{lll}
$\begin{array}{l}\text { Class and } \\
\text { Gender }\end{array}$ & $\begin{array}{l}\text { All } \\
\text { Participants }\end{array}$ & $\begin{array}{l}\text { Active- } \\
\text { Participants }\end{array}$ \\
\hline $\begin{array}{l}\text { Jigsaw Class } \\
\quad \text { Male }\end{array}$ & 20 & 7 \\
$\quad$ Female & 21 & 10 \\
NHT Class & & \\
$\quad$ Male & 22 & 14 \\
$\quad$ Female & 18 & 13 \\
\hline Total & $\mathbf{8 1}$ & $\mathbf{4 4}$ \\
\hline
\end{tabular}

allegedly not widely utilized by Science teachers in Indonesia, particularly in Bandung. To capture student perceptions of APL, students require to be acquainted with APL by using it in their learning activity.

\subsection{Sample}

Participants were determined according to the availability of school to be a location of this research. A total of 81 seventh-grade students of a public middle school in Bandung were invited to this study as participants. There was no randomization of students in this study. Student groups are the same as existing classes.

\subsection{Treatment}

Two groups of students were involved in this study. One group was designated as experimental class 1 , and another group was designated as experimental class 2. Each group learned about environmental pollution in three meetings. One APL was used as a learning source at each meeting. Students in each group were assigned to analyze the APL, beginning from the background, methods, results, discussion to conclusions. The APL analyzed by students were three APL with soil, water, and air pollution that occur in Bandung. Researchers adapted the APL from PSL published by a Department of Environmental Engineering journal from a state university in Bandung. The three APL can be viewed in associated content sections 1 to 3. A worksheet was used in this learning as a guide for students in analyzing the APL. The experimental class 1 and 2 applied a jigsaw and an NHT as the learning models, respectively.

When this research was conducted, a pandemic occurred in the form of the coronavirus outbreak that caused Covid-19. This condition caused all learning activities in schools to shift to the home and conducted online. Therefore, providing treatment to groups of students in this research was also conducted online. The media used in this learning was WhatsApp Group (WAG). This media was determined for three considerations. First, the school science teacher assessed that the students' gadgets are not yet eligible to use video-based streaming media. Second, WAG was believed by the teacher and researchers as the most widely used communication media by students. Third, WAG can send messages in various forms of media, namely texts, sounds, images, videos, and files. Thus, WAG was considered the most suitable media to be used in this learning.

\subsection{Data Collection}

After the treatment was conducted, the two groups of students were requested to fill out a questionnaire via Google Form. We told students to fill out the questionnaire honestly and according to what they experienced. We also told students that filling out the questionnaire had no impact on their Science scores. The questionnaire contained 14 statements about students' perceptions of APL in actualizing authentic Science. The statements in the questionnaire were in the form of positive and negative statements. Students can choose a scale that matches their perception in a positive statement, scale 1 for strongly disagree and scale 4 for strongly agree. In a negative statement, the opposite applies. Table 1 shows the questionnaire rubrics. This questionnaire statement's validity and reliability test item were performed at the significance level of 0.05 two-sided and $\mathrm{r}_{\text {table }}$ of 0.254 . All statements have a p-value greater than $r_{\text {table. }}$ Then all statements are declared valid and reliable. In associated content sections 4 and 5 , a complete questionnaire, validity, and reliability test are provided, respectively.

Data was collected from the end of April to the beginning of May 2020. From a total of 81 students, only 44 students were declared to be active in the research process from the first treatment to completing the questionnaire. Therefore, at the data analysis stage, only data from 44 students were processed. Participant data is shown in Table 2.

\subsection{Data Analysis}

To obtain how the level of students' perceptions of APL in actualizing authentic Science, the total scores of each student were converted into percentages. The mean percentage of each group of students is calculated and interpreted using the criteria in Table 3 (Sugiyono, 2010).

To examine the difference in perception between the two groups of students, a comparison test of the mean 
Table 3 Interpretation guideline of perception percentage

\begin{tabular}{ll}
\hline Percentage of Perception & Category \\
\hline $0-19$ & Very Low \\
$20-39$ & Low \\
$40-59$ & Moderate \\
$60-79$ & High \\
$80-100$ & Very High \\
\hline
\end{tabular}

percentage of each group was conducted. Because the data came from two different groups and had non-normal distributed data, the Mann-Whitney test has been conducted (Minium, King, \& Bear, 1993). This test can provide answers to which learning model is more effective in actualizing authentic Science by using APL. Furthermore, the effect size is also calculated to contrast the discrepancy (Minium, King, \& Bear, 1993; Thalheimer \& Cook, 2002).

\section{RESULT AND DISCUSSION}

Learning using internet media is growing and becoming a trend nowadays (Palvia et al., 2018), particularly amid a pandemic. Face-to-face teaching and learning is considered a threat to students' and teachers' health (Murphy, 2020). But in its implementation, there are still obstacles in the form of limited student access to the internet (Assareh \& Bidokht, 2011). For example, students have a poor internet connection (Pitaloka, Anggraini, Kurniawan, Erlina \& Jaya, 2020). Therefore, as many as $40 \%$ of students experienced obstacles in accessing technology used in online learning (Shahmoradi, Changizi, Mehraeen, Bashiri, Jannat \& Hosseini, 2018). This study also encountered similar obstacles. As a result, about $45 \%$ of students in this study were declared less active, so the number of active participants was only 44. Even though student involvement in learning can be improved by jigsaw (Goolsarran, Hamo $\&$ Lu, 2020) or NHT (Purnomo, 2012), the learning models applied in this study were not the two cooperative

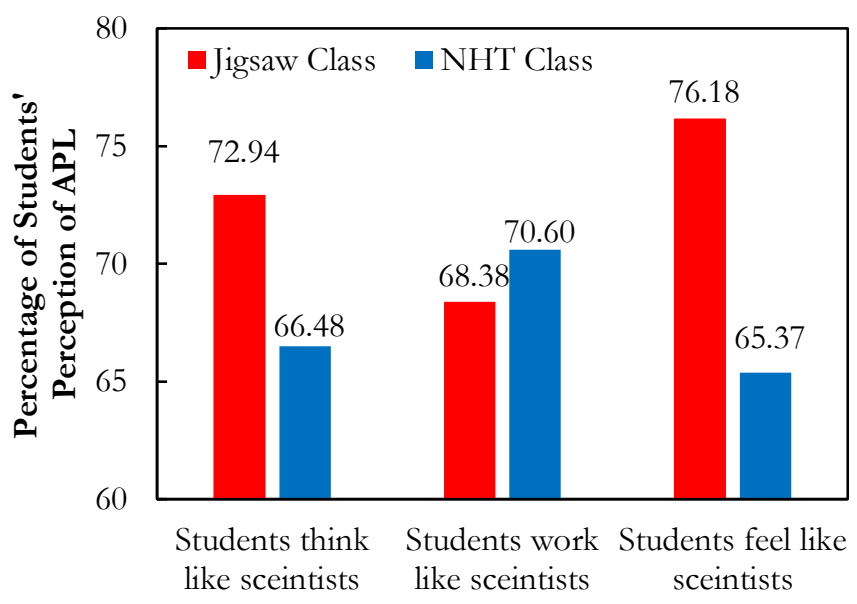

Figure 1 Percentage of students' perceptions on each indicator
Table 2 Descriptive statistics on the percentage of students' perceptions of APL

\begin{tabular}{lll}
\hline Descriptive statistics & Class Jigsaw & Class NHT \\
\hline Number of participant & 17 & 27 \\
Mean & 72.79 & 67.26 \\
Standard deviation & 10.82 & 7.18 \\
Minimum Score & 51.79 & 55.38 \\
Maximum Score & 92.86 & 82.14 \\
\hline
\end{tabular}

learnings; the number of active students could be possibly lower.

The first research question is how students' perceptions of APL in actualizing exact science. Figure 1 shows the average percentage of student's perceptions of the two indicators, and it appears that students in both classes have high perceptions of APL. All indicators also show a high perception. This can be interpreted that the use of APL in both classes has succeeded in actualizing authentic Science.

Based on data from 44 students, the use of APL as a source of Science learning has been able to actualize authentic Science. Assigning students to analyze APL means asking students to read the writings of scientists. One strategy for achieving an authentic Science is to posit students in the perspective of scientists, namely by reading their writings (Larison, 2018). Although in the form of an adaptation from scientists' writings, APL can still allow students to conduct authentic scientific activities such as those of scientists (Ford, 2009). Reading APL is also considered an authentic scientific practice (Yarden, Norris, \& Phillips, 2015a) to improve the learning process of Science based on inquiry (Ford, 2009; Yarden, Norris, \& Phillips, 2015b).

The second research question is whether there is a difference in perception of APL between students who analyze APL with jigsaw and students who analyze APL with NHT. Table 4 shows the descriptive statistics of the two classes regarding their perceptions of APL. The mean percentage of perception in the jigsaw class is higher than in the NHT class. Inferential analysis needs to be performed to prove the significance of the difference.

All test is conducted at a significance level of 0.05 . The homogeneity test for both classes produces a p-value of 0.112. This means that data from both classes are homogeneous. The normality test for data from the jigsaw class and NHT class results in p-values of 0,567 and 0,038, respectively. This means that data from the jigsaw class has a normal distribution, while data from the NHT class does not have a normal distribution. A non-parametric test (Mann-Whitney) was used to compare perceptions between the two classes. This is because the data from the NHT class are generally not distributed (Minium, King, \& Bear, 1993). The Mann-Whitney test produces a p-value of 0.054 . This means that there is no significant difference between the perception of APL of jigsaw and NHT class students in actualizing authentic science. 
Scientists can conduct research individually or in groups. When the research is conducted in groups, there is a distribution of tasks. The distribution can be different (Fraenkel, Wallen, \& Hyun, 2012). For instance, in conducting a literature review, this stage can be performed by one or several researchers (s). When several researchers perform a literature review, the distribution of tasks may be similar to the distribution of tasks when students learn with jigsaw or NHT. Jigsaw is a cooperative learning model (Goolsarran, Hamo \& Lu, 2020), and reciprocally NHT (Baker, 2013). Thus, both with jigsaw and NHT, the learning activities are similar to what scientists do when analyzing PSL. Therefore, students from the two experimental classes perceived equal learning activities. Both of them perceived that what they did was the work of scientists.

On the other hand, the value of effect size is 0.647 . This value can be interpreted as a medium effect. Commonly, the effect size is calculated from an average score of the experiment and control class. Nevertheless, both classes in this study are considered practical classes. Since the average perception percentage in the jigsaw class is higher than NHT class, it can be said that jigsaw is more effective in actualizing authentic Science even though the inferential statistic shows that both classes are the same. Applying jigsaw is possibly a more appropriate option for Science teachers to actualizing authentic Science by utilizing APL.

\section{CONCLUSION}

This study has confirmed that APL as a source of Science learning can actualize authentic Science. A significant difference did not appear between students' perceptions of APL in the jigsaw and NHT classes. The students' perception of APL in both classes was also in the high category of all measured indicators of perception. Thus, APL can be a means for Science teachers to actualize authentic Science with a more straightforward strategy, mainly if other learning strategies are almost impossible to implement because of limited resources.

Authentic Science is conducting experiments, observations, and interacting with scientists, but this study shows that reading, analyzing, and discussing APL is also considered authentic Science. These results can also be a background for strengthening the use of APL as a source of Science learning. We suggested the promotion of APL to Science teachers in Bandung notably. Thus, Science learning in Bandung is expected to be in line with the nature of Science.

This research is recognized to have several limitations. One of them is the number of participants. This was caused by this learning used online media, while online learning facilities owned by students were still not sufficient. Therefore, students encountered obstacles to be present and active in learning. Further research is suggested to conduct face-to-face learning and apply other cooperative learning models. The demographic factors of students can also be traced to examine their effect on their perception.

\section{ACKNOWLEDGMENT}

I would like to thank the Indonesia Endowment Fund for Education (LPDP) for funding my master's study. I am also grateful to Mr. Sukardi and his students who have supported and were willing to become participants in this research

\section{REFERENCES}

Achiam, M., Simony, L., \& Lindow, B. E. K. (2016). Objects prompt authentic scientific activities among learners in a museum programme. International Journal of Science Education, 38(6), 10121035. https://doi.org/10.1080/09500693.2016.1178869

Anker-Hansen, J., \& Andrée, M. (2019). In Pursuit of Authenticity in Science Education. Nordina, 15(1), 498-510.

Ariely, M., Livnat, Z., \& Yarden, A. (2019a). Analyzing the Language of an Adapted Primary Literature Article. Science \& Education, 28(1), 63-85. https://doi.org/10.1007/s11191-019-00033-5

Ariely, M., Livnat, Z., \& Yarden, A. (2019b). Analyzing the Language of an Adapted Primary Literature Article. Science \& Education, 28(1-2), 63-85. https://doi.org/10.1007/s11191-019-00033-5

Assareh, A., \& Bidokht, M. H. (2011). Barriers to e-teaching and elearning. Procedia Computer Science, 3, 791795.https://doi.org/https://doi.org/10.1016/j.procs.2010.12.129

Baker, D. P. (2013). The effects of implementing the cooperative learning structure, numbered heads together, in chemistry classes at a rural, low performing high school. Louisiana State University.

Broder, E. D., Guilbert, K. E., Tinghitella, R. M., Murphy, S. M., Ghalambor, C. K., \& Angeloni, L. M. (2019). Authentic science with dissemination increases self-efficacy of middle school students. Integrative and Comparative Biology. https://doi.org/10.1093/icb/icz140

Buxton, C. A. (2006). Creating contextually authentic science in a "lowperforming" urban elementary school. Journal of Research in Science Teaching, 43(7), 695-721. https://doi.org/10.1002/tea.20105

Cervetti, G., \& Pearson, P. (2012). Reading, Writing, and Thinking Like a Scientist. Journal of Adolescent \& Adult Literacy, 55(7), 580-586. https://doi.org/10.1002/JAAL.00069

Chapman, A. (2013). An Investigation of the Effects of Authentic Science Experiences Among Urban High School Students [University of South Florida]. http://scholarcommons.usf.edu/etd/4653

Chapman, A., \& Feldman, A. (2017). Cultivation of science identity through authentic science in an urban high school classroom. Cultural Studies of Science Education, 12(2), 469-491. https://doi.org/10.1007/s11422-015-9723-3

Crawford, B. (2013). Authentic Science. In R. Gunstone (Ed.), Encyclopedia of Science Education (pp. 1-3). Springer Netherlands. https://doi.org/10.1007/978-94-007-6165-0_144-2

Doymus, K. (2008). Teaching chemical bonding through jigsaw cooperative learning. Research in Science \& Technological Education, 26(1), 47-57. https://doi.org/10.1080/02635140701847470

Fang, Z. (2006). The language demands of science reading in middle school. International Journal of Science Education, 28(5), 491-520.

Fitriana, D., \& Oginawati, K. (2012). Studi Paparan Gas Karbon Monoksida dan Dampaknya Terhadap Pekerja di Terminal Cicaheum Bandung. Jurnal Teknik Lingkungan, 18(1), 21-29. https://doi.org/10.5614\%2Fjtl.2012.18.1.3

Ford, D. J. (2009). Promises and Challenges for the Use of Adapted Primary Literature in Science Curricula: Commentary. Research in Science Education, 39(3), 385-390. https://doi.org/10.1007/s11165008-9115-8

Fraenkel, J. R., Wallen, N. E., \& Hyun, H. H. (2012). How to Design and Evaluate Research in Education. McGraw-Hill. 
Goolsarran, N., Hamo, C. E., \& Lu, W.-H. (2020). Using the jigsaw technique to teach patient safety. Medical Education Online, 25(1), 1710325. https://doi.org/10.1080/10872981.2019.1710325

Hellgren, J. M., \& Lindberg, S. (2017). Motivating students with authentic science experiences: changes in motivation for school science. Research in Science and Technological Education, 35(4), 409-426. https://doi.org/10.1080/02635143.2017.1322572

Hidayat, T., Rustaman, N., \& Shidiq, A. S. (2020). Science Teachers' Perception of APL: What and How. Proceedings of the 2020 8th International Conference on Information and Education Technology, 169173. https://doi.org/10.1145/3395245.3396423

Komarawidjaja, W. (2017). Paparan Limbah Cair Industri Mengandung Logam Berat pada Lahan Sawah di Desa Jelegong, Kecamatan Rancaekek, Kabupaten Bandung. Jurnal Teknik Lingkungan, 18(2), 173-181.

Koomen, M. H., Rodriguez, E., Hoffman, A., Petersen, C., \& Oberhauser, K. (2018). Authentic science with citizen science and student-driven science fair projects. Science Education, 102(3), 593644. https://doi.org/10.1002/sce. 21335

Labouta, H. I., Kenny, N. A., Li, R., Anikovskiy, M., Reid, L., \& Cramb, D. T. (2018). Learning science by doing science: an authentic science process-learning model in postsecondary education. International Journal of Science Education, 40(12), 1476-1492. https://doi.org/10.1080/09500693.2018.1484966

Larison, K. D. (2018). Taking the Scientist's Perspective. Science \& Education, 27(1), 133-157. https://doi.org/10.1007/s11191-0189957-z

Leasa, M., \& Corebima, A. D. (2017). The effect of numbered heads together (NHT) cooperative learning model on the cognitive achievement of students with different academic ability. Journal of Physics: $\quad$ Conference Series, 795(012071), 1-9. https://doi.org/doi:10.1088/1742-6596/795/1/012071

Li, M. P., \& Lam, B. H. (2013). Cooperative learning. The Hong Kong Institute of Education, 1-33.

Machluf, Y., Gelbart, H., Ben-Dor, S., \& Yarden, A. (2017). Making authentic science accessible-the benefits and challenges of integrating bioinformatics into a high-school science curriculum. Briefings in Bioinformatics, 18(1), 145-159. https://doi.org/10.1093/bib/bbv113

McCoach, D. B., Gable, R. K., \& Madura, J. P. (2013). Affective Characteristics in School and Corporate Environments: Their Conceptual Definitions BT - Instrument Development in the Affective Domain: School and Corporate Applications (D. B. McCoach, R. K. Gable, \& J. P. Madura (eds.); pp. 1-32). Springer New York. https://doi.org/10.1007/978-1-4614-7135-6_1

Minium, E. D., King, B. M., \& Bear, G. (1993). Statistical Reasoning in Psychology and Education (Third Edit). John Wiley \& Sons.

Mulyana, M. A., Hanifah, N., \& Jayadinata, A. K. (2016). Penerapan Model Kooperatif Tipe Numbered Heads Together (NHT) Untuk Meningkatkan Hasil Belajar Siswa Pada Materi Kenampakan Alam Dan Sosial Budaya. Jurnal Pena Imiah, 1(1), 331-340.

Munn, M., Knuth, R., Van Horne, K., Shouse, A. W., \& Levias, S. (2017). How do you like your science, wet or dry? How two lab experiences influence student understanding of science concepts and perceptions of authentic scientific practice. CBE Life Sciences Education, 16(2), ar39. https://doi.org/10.1187/cbe.16-04-0158

Murphy, M. P. A. (2020). COVID-19 and emergency eLearning: Consequences of the securitization of higher education for postpandemic pedagogy. Contemporary Security Policy, 1-14. https://doi.org/10.1080/13523260.2020.1761749

Nurbianta, N., \& Dahlia, H. (2018). The effectiveness of Jigsaw method in improving students reading comprehension. ETERNAL (English Teaching Journal), 9(1).

OECD. (2019). PISA 2018 Results (Volume I). OECD. https://doi.org/10.1787/5f07c754-en

Olitsky, S., Becker, E. A., Jayo, I., Vinogradov, P., \& Montcalmo, J. (2018). Constructing "Authentic" Science: Results from a University/High School Collaboration Integrating Digital
Storytelling and Social Networking. Research in Science Education, $1-$ 24. https://doi.org/10.1007/s11165-018-9699-6

Palvia, S., Aeron, P., Gupta, P., Mahapatra, D., Parida, R., Rosner, R., \& Sindhi, S. (2018). Online Education: Worldwide Status, Challenges, Trends, and Implications. Journal of Global Information Technology Management, 21(4), 233-241. https://doi.org/10.1080/1097198X.2018.1542262

Phillips, L. M., \& Norris, S. P. (2009). Bridging the Gap Between the Language of Science and the Language of School Science Through the Use of Adapted Primary Literature. Research in Science Education, 39(3), 313-319. https://doi.org/10.1007/s11165-008-9111-z

Pitaloka, N. L., Anggraini, H. W., Kurniawan, D., Erlina, E., \& Jaya, H. P. (2020). Blended Learning in a Reading Course: Undergraduate EFL Students' Perceptions and Experiences. IRJE |Indonesian Research Journal in Education|, 4(1), 43-57. https://onlinejournal.unja.ac.id/irje/article/view/8790

Prilia, D., \& Kamil, I. M. (2011). Penentuan Kualitas Air Tanah Dangkal Berdasarkan Parameter Mikrobiologi (Studi Kasus: Kecamatan Ujungberung, Kota Bandung). Jurnal Teknik Lingkungan, 17(2), 1121.

Purnomo, S. (2012). Improving the Students' Reading Comprehension through Numbered Heads Together Technique. Journal on English as a Foreign Language, 2(2), 37-44.

Rivera Maulucci, M. S., Brown, B. A., Grey, S. T., \& Sullivan, S. (2014). Urban middle school students' reflections on authentic science inquiry. Journal of Research in Science Teaching, 51(9), 1119-1149. https://doi.org/10.1002/tea.21167

Rusilowati, A. (2014). Analisis buku ajar IP A yang digunakan di Semarang berdasarkan muatan literasi sains.

Shahmoradi, L., Changizi, V., Mehraeen, E., Bashiri, A., Jannat, B., \& Hosseini, M. (2018). The challenges of E-learning system: Higher educational institutions perspective. Journal of Education and Health Promotion, 7, 116. https://doi.org/10.4103/jehp.jehp_39_18

Slavin, R. E. (1980). Cooperative Learning. Review of Educational Research, 50(2), 315-342. https://doi.org/10.3102/00346543050002315

Slavin, R. E. (2012). Classroom applications of cooperative learning. In APA educational psychology bandbook, Vol 3: Application to learning and teaching. (pp. 359-378). American Psychological Association. https://doi.org/10.1037/13275-014

Sugiyono. (2010). Metode Penelitian Pendidikan: Pendekatan Kuantitatif, Kualitatif, dan R\&D. Penerbit Alfabeta.

Tala, S., \& Vesterinen, V.-M. (2015). Nature of Science Contextualized: Studying Nature of Science with Scientists. Science \& Education, 24(4), 435-457. https://doi.org/10.1007/s11191-014-9738-2

Tarhan, L., Ayyıldız, Y., Ogunc, A., \& Sesen, B. A. (2013). A jigsaw cooperative learning application in elementary science and technology lessons: physical and chemical changes. Research in Science \& Technological Education, 31(2), 184-203. https://doi.org/10.1080/02635143.2013.811404

Thalheimer, W., \& Cook, S. (2002). How to calculate effect sizes from published research: A simplified methodology. Work-Learning Research, 1, 1-9.

Tsybulsky, D. (2019). Students meet authentic science: the valence and foci of experiences reported by high-school biology students regarding their participation in a science outreach programme. International Journal of Science Education, 41(5), 567-585. https://doi.org/10.1080/09500693.2019.1570380

Upahi, J. E., Ramnarain, U., \& Ishola, I. S. (2018). The Nature of Science as Represented in Chemistry Textbooks Used in Nigeria. Research in Science Education. https://doi.org/10.1007/s11165-018-9734-7

Vesterinen, V.-M., Aksela, M., \& Lavonen, J. (2013). Quantitative analysis of representations of nature of science in Nordic upper secondary school textbooks using framework of analysis based on philosophy of chemistry. Science \& Education, 22(7), 1839-1855.

Wahyu, E., \& Markos, S. (2016). Analisis buku siswa mata pelajaran IPA kelas VIII SMP/Mts berdasarkan kategori literasi sains. Jurnal Inovasi Dan Pembelajaran Fisika, 3(2). 
Ward, T. J., Delaloye, N., Adams, E. R., Ware, D., Vanek, D., Knuth, R., Hester, C. L., Marra, N. N., \& Holian, A. (2016). Air Toxics Under the Big Sky: examining the effectiveness of authentic scientific research on high school students' science skills and interest. International Journal of Science Education, 38(6), 905-921. https://doi.org/10.1080/09500693.2016.1167984

Yarden, A. (2009). Reading Scientific Texts: Adapting Primary Literature for Promoting Scientific Literacy. Research in Science Education, 39(3), 307-311. https://doi.org/10.1007/s11165-009-9124-2

Yarden, A., Norris, S. P., \& Phillips, L. M. (2015a). Adapting Primary Literature for Promoting Scientific Literacy. In A. Yarden, S. P. Norris, \& L. M. Phillips (Eds.), Adapted Primary Literature: The Use of Authentic Scientific Texts in Secondary Schools (pp. 15-31). Springer Netherlands. https://doi.org/10.1007/978-94-017-9759-7_2

Yarden, A., Norris, S. P., \& Phillips, L. M. (2015b). APL and Reading in Science Classrooms. In A. Yarden, S. P. Norris, \& L. M. Phillips (Eds.), Adapted Primary Literature: The Use of Authentic Scientific Texts in Secondary Schools (pp. 59-80). Springer Netherlands. https://doi.org/10.1007/978-94-017-9759-7_4

Yoruk, A. (2016). Effect of Jigsaw Method on Students' Chemistry Laboratory Achievement. International Journal of Educational Sciences, 15(3), $377-381$. https://doi.org/10.1080/09751122.2016.11890547. 